\title{
HUBUNGAN BEBAN KERJA PERAWAT DAN PELAKSANAAN \\ PERSONAL HYGIENE DI RUANG RAWAT INAP BEDAH \\ PRIA/WANITA DAN BEDAH SARAF RSUD DOKTER SOEDARSO PONTIANAK
}

\author{
The Correlation Between Nurse Workload And Personal Hygiene \\ Implementation In Inpatient Room For Male/Female Surgery And \\ Neusrosurgery At RSUD Dokter Soedarso Pontianak
}

Imelda Verawaty Lumban Gaol*, Mita**, Sukarni***

* Mahasiswi Prodi Keperawatan Fakultas Kedokteran Universitas Tanjungpura, Pontianak imeldalumbangaol25@gmail.com ** Dosen Keperawatan Fakultas Kedokteran Universitas Tanjungpura, Pontianak mita@ners.untan.ac.id ***Dosen Keperawatan Fakultas Kedokteran Universitas Tanjungpura, Pontianak sukarni@ners.untan.ac.id

\begin{abstract}
ABSTRAK
Latar Belakang: Beban kerja yang tinggi dapat menurunkan produktifitas perawat dan akan berdampak pada pelayanan yang diberikan. Personal hygien merupakan salah satu bentuk pelayanan yang perawat berikan kepada pasien immobilisasi. Ruang rawat inap bedah pria/wanita dan bedah saraf RSUD Dokter Soedarso Pontianak terdapat kesenjangan antara jumlah perawat dengan jumlah pasien, sehingga berdampak pada pelaksanaan personal hygiene. Semakin tinggi beban kerja perawat, maka semakin besar peluang tidak terlaksananya personal hygiene.

Tujuan: Mengetahui hubungan antara beban kerja perawat dan pelaksanaan personal hygiene di ruang rawat inap bedah pria/wanita dan bedah saraf RSUD Dokter Soedarso Pontianak.

Metode: Penelitian kuantitatif, menggunakan metode observasional analitik korelasi dengan pendekatan cross sectional. Pengambilan sampel menggunakan metode total sampling dengan jumlah 50 responden, 25 perawat dan 25 pasien. Data penelitian menggunakan uji statistik spearman.

Hasil: Nilai $p$ value $=0,000(\mathrm{p}<0,01)$, dengan $r=-0,668$ menunjukkan bahwa arah korelasi tidak searah dengan kekuatan korelasi yang kuat yaitu beban kerja perawat dalam kategori tinggi dan pelaksanaan personal hygiene tidak terlaksana.

Kesimpulan: Ada hubungan antara beban kerja perawat dan pelaksanaan personal hygiene di ruang rawat inap bedah pria/wanita dan bedah saraf RSUD Dokter Soedarso Pontianak.
\end{abstract}

Kata Kunci: Beban Kerja Perawat, Personal Hygiene 


\begin{abstract}
ABSTACTS
Background: The high workload can reduce the productivity of nurses and will have an impact on the services provided. Personal hygiene is a form of implementation that nurses provide to immobilized patients. There is a gap between the number of nurses and the number of patients in inpatient room for male/female surgery and neurosurgery that leads to poor implementation of personal hygiene The higher workload of the nurse, the greater the chance of not implementing a good personal hygiene.

Aim: To determine the correlation between nurse workload and personal hygiene implemantation in inpatient room for male/female surgery and neurosurgery at RSUD Dokter Soedarso Pontianak.

Method: The research is a quantitative research with observational correlation analytic research method with cross sectional design. Sampling by total sampling method with a total of 50 respondents, 25 nurses and 25 patient. The research using Spearman test.

Result: $P$-value $=0,000(p<0,01)$ with $r=-0,668$ indicating that the direction of the correlation is not aligned with the strength of a strong correlation that is the nurse workload in the high category and the implemantation of personal hygiene is not implemented.

Conclusion: There is a correlation between nurses workload and personal hygiene implementation in inpatient room for male/female surgery and neurosurgery at the RSUD Dokter Soedarso Pontianak.
\end{abstract}

Keywords: Nurse Workload, Personal Hygiene 


\section{PENDAHULUAN}

Personal hygiene merupakan perawatan diri untuk merawat fungsifungsi tertentu dari anggota tubuh seperti merawat rambut, merawat gigi dan mulut, merawat kuku, melakukan vulva hygiene, serta memandikan klien ${ }^{1}$.

Personal hygiene merupakan salah satu kegiatan keperawatan langsung. Personal hygiene bermanfaat dalam pencegahan infeksi, meningkatkan sirkulasi, mempertahankan integritas jaringan dan pasien dapat merasa lebih tenang dan rileks. Salah satu kondisi pasien yang membutuhkan personal hygiene adalah pasien yang mengalami keterbatasan dalam bergerak (immobilisasi) $^{2}$.

Kebersihan diri kurang diperhatikan dan bahkan dianggap sebagai suatu masalah yang biasa saja oleh pasien maupun perawat ${ }^{3}$. Sejalan dengan penelitian Juliada tentang tingkat kepuasan pasien immobilisasi dalam pemenuhan pelaksanaan personal hygiene oleh perawat di Rumah Sakit Umum Pusat Haji Adam Malik Medan diperoleh hasil untuk pelaksanaan personal hygiene oleh perawat sangat tidak memuaskan ${ }^{4}$.

Penelitian yang dilakukan oleh Azza $\mathrm{H}$ di Mesir diperoleh hasil bahwa perawat yang bertugas dalam perawatan kritis (ICU) memiliki keterampilan dan pengetahuan yang kurang dalam memandikan pasien di tempat tidur" Selain kurangnya keterampilan dan pengetahuan terdapat beberapa faktor lain yang mempengaruhi perawat dalam melaksanakan kegiatan personal hygiene yaitu sumber daya finansial, kurangnya peralatan, tidak ada kebijakan dan beban kerja perawat ${ }^{5}$.

Beban kerja di rumah sakit meliputi beban kerja fisik dan beban kerja mental. Beban kerja fisik terdiri dari mengangkat pasien, mendorong brankar, serta pemenuhan personal hygiene pasien ${ }^{6}$.

Beban kerja dapat mempengaruhi kinerja perawat dalam memberikan pelayanan keperawatan. Beban kerja perawat yang tinggi dapat mempengaruhi pelayanan kesehatan yang kurang memuaskan ditambah lagi dengan peningkatan jumlah pasien setiap harinya ${ }^{7}$.

Sejalan dengan penelitian Rendra bahwa ada hubungan antara beban kerja perawat dengan mutu pelayanan keperawatan di rawat inap Rumah Sakit Umum Daerah Sultan Syarif Mohamad Alkadrie Kota Pontianak, semakin tinggi beban kerja perawat, maka semakin rendah mutu pelayanan keperawatan, hal ini dikarenakan seseorang yang bekerja dengan beban kerja maksimal akan menyebabkan produktivitas menurun dan mengalami kelelahan, perawat tidak fokus dan tidak berkonsentrasi saat memberikan pelayanan. Perawat hanya berfokus pada penyelesaian tugas saja tanpa memperhatikan sikap dan perilaku terhadap pasien yang sedang ditangani. Hal ini mengakibatkan penurunan kepuasan pasien terhadap pelayanan keperawatan yang diberikan ${ }^{8}$.

Hasil studi pendahuluan mengenai beban kerja perawat kepada 8 perawat pelaksana dan pelaksanaan personal hygiene kepada 10 pasien rawat inap di ruang rawat inap $\mathrm{K}$ dan L RSUD Dokter Soedarso Pontianak didapatkan 
bahwa untuk pelaksanaan personal hygiene perawat tidak lakukan sepenuhnya, perawat melibatkan keluarga hal tersebut dikarenakan jumlah perawat yang kurang dan aktivitas keperawatan yang sudah cukup padat. Untuk pasien sebagian besar mengatakan kurang puas dengan pelayanan personal hygiene dimana ada beberapa kondisi pasien yang terlihat kurang rapi dan ada bau yang tidak sedap. Untuk pelaksanaan mandi, keramas, sikat gigi serta memakaikan pakaian kepada pasien perawat meminta keluarga untuk melaksanakannya, untuk perawatan kuku kurang diperhatikan, dan untuk pasien yang terpasang kateter jarang dilaksanakan pembersihan hanya membuang urine yang ada dikantong.

Dari hasil studi pendahuluan penulis tertarik untuk melakukan penelitian terkait dengan "Hubungan Beban Kerja Perawat Dan Pelaksanaan Personal Hygiene Di Ruang Rawat Inap Bedah Pria/Wanita Dan Bedah Saraf RSUD Dokter Soedarso Pontianak.

\section{BAHAN DAN METODE}

Penelitian ini merupakan penelitian analitik dengan hipotesis Korrelatif. Desain yang digunakan dalam penelitian ini adalah Cross Sectional. Sampel yang diteliti perawat pelaksana dan pasien. Pengambilan sampel menggunakan metode total sampling dengan jumlah responden sebanyak 25 perawat pelaksana dan 25 pasien diruang rawat inap bedah pria/wanita dan bedah saraf RSUD Dokter Soedarso Pontianak.

Instrumen yang digunakan pada penelitian ini adalah kuesioner penilaian beban kerja yang berjumlah 30 pertanyaan dan kuesioner pelaksanaan personal hygiene yang berjumlah 15 pertanyaan.

Analisa data pada penelitian ini menggunakan analisis statistik komputer. Setelah data terkumpul kemudian dilakukan pengelolaan data dengan menggunakan Uji Korelasi Spearman.

\section{HASIL DAN PEMBAHASAN}

\section{Hasil Univariat}

Tabel 1

Distribusi Karakteristik Perawat

\begin{tabular}{lcc}
\hline $\begin{array}{c}\text { Karakteristik } \\
\text { Perawat }\end{array}$ & $\begin{array}{c}\text { Frekuensi } \\
\text { (f) }\end{array}$ & $\begin{array}{c}\text { Persentase } \\
(\%)\end{array}$ \\
\hline Usia & 17 & $68 \%$ \\
21-35 Tahun & 17 & $16 \%$ \\
36-45 Tahun & 4 & $16 \%$ \\
46-65 Tahun & 4 & $16 \%$ \\
Jenis Kelamin & & $84 \%$ \\
Laki-Laki & 4 & \\
Perempuan & 21 & $4 \%$ \\
Pendidikan & & $68 \%$ \\
SPR/SPK & 1 & $8 \%$ \\
D3 & 17 & $20 \%$ \\
S1 & 2 & \\
Ners & 5 & $56 \%$ \\
Lama Kerja & & $12 \%$ \\
$<5$ Tahun & 14 & $32 \%$ \\
5-10 Tahun & 3 & \\
$>10$ Tahun & 8 & $48 \%$ \\
Status & & $52 \%$ \\
Kepegawaian & & \\
Kontrak & 12 & \\
Tetap & 13 &
\end{tabular}

Tabel 1 menunjukkan untuk karakteristik usia perawat sebagian besar pada usia 21-35 tahun sebanyak 17 perawat (68\%). Usia 2135 tahun termasuk golongan usia dewasa dini dimana kemampuan motorik pada puncaknya seperti lebih cepat, seimbang dan optimal dalam melaksanakan tugas9, akan tetapi perawat dewasa muda masih kurang perilaku caring karena perawat dewasa muda belum mampu 
mengendalikan emosional pribadi, kurang disiplin, sering berpindah tempat bekerja, belum mampu berpikir rasional dan masih memerlukan bimbingan dan arahan dalam menjalankan tugas ${ }^{10}$.

Hasil penelitian mayoritas perawat berada dalam usia produktif sehingga menjadi hal yang baik untuk regenerasi tenaga keperawatan. Perawat yang produktif akan bekerja dengan tenaga yang prima dan mampu berpikir kritis walaupun belum memiliki pengalaman yang banyak dibanding perawat dewasa tua.

Proporsi perawat yang paling banyak berjenis kelamin perempuan yakni 21 perawat $(84 \%)$. Penelitian Soeprodjo, Mandagi, \& Engkeng menyatakan tidak ada hubungan antara jenis kelamin perawat dengan kinerja perawat ${ }^{11}$. Hasil penelitian Susanti juga menyatakan bahwa perawat laki-laki dan perempuan memiliki motivasi yang baik dalam memenuhi kebutuhan kebersihan diri pasien $^{12 .}$

Karakteristik tingkat pendidikan perawat yang paling banyak lulusan Diploma III sebanyak 17 perawat (68\%). Penelitian Malik menyatakan bahwa terdapat hubungan antara pendidikan perawat dengan mutu pelayanan keperawatan yang perawat berikan kepada pasien ${ }^{13}$. Sejalan dengan penelitian Elysabeth, Libranty, \& Natalia menunjukkan hasil bahwa ada hubungan antara tingkat pendidikan dengan kompetensi perawat dalam melakukan Evidence-Based Practice (EBP) di Rumah Sakit Siloam, dimana semakin tinggi tingkat pendidikan perawat maka semakin baik kompetensi perawat dalam melaksnakan $\mathrm{EBP}^{14}$.

Proporsi perawat yang paling banyak bekerja $<5$ tahun yakni sebanyak 14 perawat (56\%). Penelitian Susanti terdapat hubungan antara lama bekerja perawat dengan motivasi perawat dalam memberikan pemenuhan kebutuhan kebersihan diri $^{12}$. Penlitian Faizin menunjukkan hasil bahwa ada hubungan antara lama kerja perawat terhadap kinerja perawat di Rumah Sakit Umum Pandan Arang Kabupaten Boyolali, dimana perawat senior memiliki kinerja tinggi sedangkan perawat yang junior masih perlu pengembangan dan pembinaan ${ }^{15}$.

Dan untuk status kepegawaian sebagian besar perawat tetap yakni sebanyak 13 perawat (52\%). Penelitian Abas menyatakan hasil bahwa perawat dengan status pegawai tetap atau Pegawai Negeri Sipil (PNS) memiliki motivasi kerja yang lebih tinggi ${ }^{16 .}$

Tabel 2

Distribusi Karakteristik Pesien

\begin{tabular}{lcc}
\hline $\begin{array}{c}\text { Karakteristik } \\
\text { Pasien }\end{array}$ & $\begin{array}{c}\text { Frekuensi } \\
\text { (f) }\end{array}$ & $\begin{array}{c}\text { Persentase } \\
\text { (\%) }\end{array}$ \\
\hline Jenis Kelamin & 11 & $44 \%$ \\
Laki-Laki & 14 & $56 \%$ \\
Perempuan & & \\
Usia & 3 & $12 \%$ \\
17-25 Tahun & 9 & $36 \%$ \\
26-45 Tahun & 11 & $44 \%$ \\
46-65 Tahun & 2 & $8 \%$ \\
>65 Tahun & & \\
Pendidikan & 4 & $16 \%$ \\
Tidak Sekolah & 6 & $24 \%$ \\
SD & 7 & $28 \%$ \\
SMP & 8 & $32 \%$ \\
SMA & & \\
Pekerjaan & 12 & $48 \%$ \\
Tidak Bekerja & 8 & $32 \%$ \\
Swasta & 5 & $20 \%$ \\
Petani & & \\
Kategori & & \\
Perawatan & 18 & $72 \%$ \\
Parsial & 7 & $28 \%$ \\
Total & & \\
\hline
\end{tabular}


Tabel 2 menunjukkan untuk proporsi pasien yang paling banyak berjenis kelamin perempuan 14 pasien (56\%). Jenis kelamin memiliki pengaruh terhadap cara pandang terhadap jasa yang diberikan ${ }^{17}$. Penelitian Afrilianti menyatakan bahwa responden yang terbanyak perempuan hal ini dikarenakan perempuan lebih cenderung lebih tanggap dalam pencegahan penyakit dari pengenalan awal timbulnya penyakit dan segera mengobatinya serta mempunyai perhatian yang tinggi dengan kesehatan ${ }^{18}$.

Karakteristik usia pasien sebagian besar berusia 46-65 tahun yakni 11 pasien (44\%). usia 46-55 tahun termasuk dalam kategori lansia awal, hal ini dikarenakan bertambahnya usia seseorang akan mengakibatkan kemunduran struktur dan fungsi organ sehingga masyarakat usia tua cenderung memanfaatkan pelayan kesehatan dibanding usia muda ${ }^{17}$. Penelitian Akbulut, Kant, Ozmen dan Akpinar juga sejalan, pasien yang dirawat inap dengan usia terbanyak 41-65 tahun. Hal ini menunjukkan bahwa kelompok umur lansia awal dan akhir merupakan tahap dimana seseorang mengalami berbagai penurunan daya tahan tubuh dan berbagai tekanan psikologis dengan demikian akan timbul perubahan perubahan dalam hidupnya ${ }^{19}$.

Karakteristik pendidikan pasien sebagain besar pendidikan SMA yakni 8 pasien $(32 \%)$. Penelitian Setiawan dan Kariasa sejalan, yang menyatakan bahwa tingkat kepuasan pada orang yang berpendidikan berbeda dikarenakan orang yang berpendidikan rendah jarang memikirkan hal-hal yang ada diluar nalarnya sehingga mudah merasakan kepuasan sedangkan yang berpendidikan tinggi lebih cenderung untuk memenuhi kebutuhannya dan cenderung merasa tidak puas ${ }^{20}$.

Karakteristik pekerjaan pasien sebagian besar tidak bekerja yakni 12 pasien (48\%). Penelitian Setiawan dan Kariasa menyatakan hal pekerjaan seseorang sangat mempengaruhi kepuasan. Seseorang yang bekerja memiliki harapan yang sangat tinggi terhadap pelayanan kesehatan dibandingkan dengan orang yang tidak bekerja ${ }^{20}$. Kategori perawatan pasien sebagian besar adalah perawatan parsial yakni 18 pasien $(72 \%)$.

\section{Tabel 3}

Distribusi Karakteristik Beban Kerja Perawat

\begin{tabular}{ccc}
\hline Beban Kerja & $\begin{array}{c}\text { Frekuensi } \\
\text { (f) }\end{array}$ & $\begin{array}{c}\text { Persentase } \\
(\mathbf{\%})\end{array}$ \\
\hline Tinggi & 11 & $44 \%$ \\
Sedang & 9 & $36 \%$ \\
Rendah & 5 & $20 \%$ \\
\hline
\end{tabular}

Tabel 3 menunjukkan bahwa karakteristik beban kerja perawat pelaksana sebagian besar kategori tinggi yakni sebanyak 11 perawat (44\%). Berdasarkan data yang di dapat dari kedua ruangan, rata-rata Bed Occupancy Ratio (BOR) pada ruang rawat inap bedah pria/wanita dan bedah saraf masing-masing $81 \%$ dan 75\%. Akan tetapi dengan tingginya angka penggunaan tempat tidur tidak diimbangi dengan jumlah perawat, hal tersebut yang membuat perawat kelelahan dalam menangani pasien.

Hasil dari penelitian ini sejalan dengan penelitian yang dilakukan Retnaningsih \& Fatmawati yang menunjukkan hasil bahwa kategori 
beban kerja tinggi dikarenakan jumlah pasien dengan macammacam tingkat kebutuhan perawatan tidak sebanding dengan perawat yang ada diruangan sehingga tingkat beban kerja perawat dalam kategori berat $^{21}$. Bogaert \& Clarke beban kerja dapat menimbulkan kejenuhan dalam praktik keperawatan (dipengaruhi dengan hubungan interprofesional yang kurang harmonis) dan berdampak buruk pada kualitas pelayanan keperawatan yang diberikan termasuk pelaksanaan personal hygiene $e^{22}$.

Pada lembar jawab responden rata-rata hasil menunjukkan perawat di kedua ruangan dalam kategori beban kerja tinggi. Hal ini terlihat dari tiga aspek yang tertera dalam kuesioner penelitian, dimana untuk aspek fisik beban kerja tinggi disebabkan volume pekerjaan yang banyak, jumlah pasien yang dirawat pada setiap perawat bisa hingga 5-6 pasien, kemudian tingkat ketergantungan pasien dan lama pasien dirawat lebih dari 1 minggu dan kelelahan dalam menjalankan tugas.

Aspek psikologis perawat beban kerja tinggi karena bebarapa perawat merasa atasan kurang memberikan pengarahan terkait pelaksanaan tugas, beberapa perawat merasa jenuh dan adanya beberapa tuntutan yang perawat terima dari keluaraga pasien Untuk aspek waktu kerja beban kerja perawat tinggi dikarenakan ada beberapa rekan perawat yang datang tidak tepat waktu sehingga pergantian shift kerja mundur karena jumlah perawat tiap shift yang kurang sesuai dengan beban kerja yang menjadi tanggung jawab perawat. Dengan beban kerja yang tinggi terkadang membuat perawat tidak memberikan personal hygiene kepada pasien.

Tabel 4

Distribusi Karakteristik Pelaksanaan Personal Hygiene

\begin{tabular}{ccc}
\hline $\begin{array}{c}\text { Personal } \\
\text { Hygiene }\end{array}$ & $\begin{array}{c}\text { Frekuensi } \\
\text { (f) }\end{array}$ & $\begin{array}{c}\text { Persentase } \\
(\mathbf{\%})\end{array}$ \\
\hline Terlaksana & 11 & $44 \%$ \\
Tidak Terlaksana & 14 & $56 \%$ \\
\hline
\end{tabular}

Tabel 4 menunjukkan bahwa karakteristik pelaksanaan personal hygiene sebagian besar dengan kategori tidak terlaksana yakni sebanyak 14 pasien (56\%). Penelitian Nikijuluw menunjukkan hasil bahwa untuk pelaksanaan personal hygiene dalam kategori sangat rendah $^{23}$. Menurut penelitian Awiktamarotun didapatkan hasil bahwa pelaksanaann personal hygiene dalam kategori cukup $^{24}$. Terkait faktor pelaksanaan personal hygiene masih minimnya pelaksanaan personal hygiene dalam kategori baik karena dipengaruhi status sosial ekonomi dan pendidikan. Tingkat pendidikan yang kurang dan status ekonomi yang rendah tentu akan mempengaruhi pengetahuan akan personal hygiene . $^{25}$.

Perawat pelaksana di kedua ruangan jarang membantu pasien dalam pemenuhan kebersihan diri, ada beberapa pasien yang perawat berikan personal hygiene dan hari selanjutnya menyerahkan kepada keluarga pasien. Kegiatan personal hygiene yang dilaksanakan perawat kepada pasien, yaitu mengingatkan/membantu mengelap/ memandikan pasien, mengingatkan/ membantu dalam berkeramas, mengingatkan/membantu pasien dalam menjaga kebersihan mulut dan 
gigi, mengganti seprai dan pakaian kotor. Sedangkan untuk kegiatan personal hygiene yang jarang dilaksanakan perawat adalah kegiatan memotong kuku dan memberikan lotion sehabis mandi kepada perawat, hal ini dikarenakan kegiatan tersebut dapat dilakukan sendiri oleh pasien ataupun keluarga pasien.

Personal hygiene dilaksanakan perawat berdasarkan kemampuan dari pasien jika memang pasien sangat butuh bantuan, perawat akan membantu, namun jika masih ada keluarga dan pasien masih mampu perawat tidak lakukan. Hal ini terjadi dikarenakan tenaga perawat yang tidak cukup untuk melaksanakan personal hygiene kepada semua pasien.

\section{Hasil Bivariat}

Tabel 5

Hubungan Beban Kerja Perawat dan Pelaksanaan Personal Hygiene Di Ruang Rawat Inap Bedah Pria/Wanita dan Bedah Saraf RSUD Dokter Soedarso

\begin{tabular}{ccc}
\hline & & $\begin{array}{c}\text { Skor Personal } \\
\text { Hygiene }\end{array}$ \\
\hline Skor Beban & $R$ & $-0,668$ \\
Kerja & $p$ & $<0,01$ \\
& $\mathrm{n}$ & 25 \\
\hline
\end{tabular}

Tabel 5 menunjukkan nilai significancy yaitu $0,000<0,01$ menunjukkan bahwa korelasi antara beban kerja perawat dan pelaksanaan personal hygiene adalah bermakna dengan nilai korelasi Spearman sebebar -0,668 menunjukkan bahwa arah korelasi negatif (tidak searah) dengan kekuatan korelasi yang kuat dimana semakin tinggi beban kerja perawat maka pelaksanaan personal hygiene tidak terlaksana. Adapun kesimpulan yaitu ada hubungan yang signifikan antara beban kerja perawat dan pelaksanaan personal hygiene.

Sejalan dengan penelitian Saputra menunjukkan bahwa terdapat hubungan antara beban kerja perawat dengan mutu pelayanan keperawatan di rawat inap Rumah Sakit Umum Daerah Sultan Syarif Mohamad Alkadrie Kota Pontianak dimana perawat memiliki beban kerja tinggi dan mutu pelayanan keperawatan rendah. Dengan kesimpulan bahwa semakin tinggi beban kerja perawat, maka semakin rendah mutu pelayanan keperawatan $^{8}$.

Penelitian Runtu, Pondaag, \& Hamel didapatkan hasil bahwa perawat yang bekerja di rumah sakit GMIM Manado memiliki beban kerja fisik yang tinggi dimana perawat dituntut menjadi tenaga kesehatan cepat, tepat dan cekatan dalam memberikan asuhan keperawatan kepada pasien, memiliki kinerja yang baik dalam menangani karakter pasien yang berbeda-beda sehingga mengakibatkan perawat merasa keletihan yang menyebabkan stres kerja pada perawat. ketika seseorang mengalami stres tingkat tinggi dapat mempengaruhi kondisi kesehatan perawat dalam bekerja dan akan berdampak pada hasil kinerjanya. Dapat disimpulkan terdapat hubungan antara beban kerja fisik dengan stres kerja perawat ${ }^{26}$.

Gambaran beban kerja perawat yang tinggi dikarenakan perawat yang harus mendampingi dokter yang sedang visite, pasien yang dirawat memiliki tingkat ketergantungan parsial dan total, kemudian adanya tuntutan dari keluarga pasien yang perawat terima, lama rawat pasien yang dapat 
mencapai 1 minggu, beberapa perawat yang merasa jenuh dan terkadang pergantian shift mundur karena ada beberapa rekan kerja perawat yang dinas tidak tepat waktu. Beban kerja perawat yang tinggi dapat menyebabkan kelelahan fisik maupun psikis bagi perawat, hal ini akan mempengaruhi semangat dan keinginan perawat untuk memberikan personal hygiene kepada pasien.

Tinggi rendahnya beban kerja perawat dapat diukur dari tiga aspek yaitu aspek fisik, psikologis dan waktu kerja. Jika ketiga aspek belebih maka dapat menurunkan kinerja perawat. Beban keja yang tinggi juga berdampak pada timbulnya kelelahan fisik dan psikis sehingga menurunkan kemampuan kerja serta beban kerja yang tinggi akan mempengaruhi kualitas kerja perawat salah satunya dalam pelaksanan personal hygiene.

Dari hasil penelitian didapatkan bahwa untuk pelaksanaan personal hygiene tidak terlaksana hal ini dipengaruhi dari beban kerja perawat yang tinggi. Pelaksanaan personal hygiene dilaksanakan tergantung dari kondisi pasien. Perawat rata-rata jarang membantu pasien dalam memandikan, berkeramas, membersihkan mulut, potong kuku, perawat lebih sekedar mengingatkan pasien dan keluarga, kadang-kadang perawat hanya melakukan sekali untuk hari selanjutnya perawat mengandalkan peran dari keluarga pasien dan ada beberapa perawat, jika kondisi pasien dan seprai benarbenar sudah kotor baru perawat membersihkan. Untuk kegiatan personal hygiene yang tidak pernah dilakukan perawat yaitu memberikan loition dan perawatan kuku kaki dan tangan pasien, hal ini dikarenakan menurut perawat kegiatan tersebut dapat dilaksanakan oleh keluarga pasien. Perawat membantu memberikan pelayanan personal hygiene dikarenakan pasien termasuk kategori total care yang memang membutuhkan bantuan dari perawat.

\section{SIMPULAN DAN SARAN}

Hasil penelitian didapatkan beban kerja perawat pelaksana sebagian besar pada kategori tinggi dan pelaksanaan personal hygiene sebagian besar pada kategori tidak terlaksana. Terdapat hubungan antara beban kerja perawat dan pelaksanaan personal hygiene di ruang rawat inap bedah pria/wanita dan bedah saraf RSUD Dokter Soedarso Pontianak.

Bagi manajemen rumah sakit diharapkan dapat menghitung kebutuhan tenaga kesehatan yang dibutuhkan dan menyusun setiap tugas tenaga kesehatan, kegiatan perawat yang bersifat kolaboratif dapat dialihkan sesuai dengan kompetensi tenaga profesional yang lain agar beban kerja perawat menjadi stabil dan kualitas pelayanan salah satunya terhadap pelaksanaan personal hygiene di ruang rawat inap RSUD Dokter Soedarso Pontianak dapat berjalan dengan baik.

Dapat mengembangkan hasil penelitian ini dengan metode yang berbeda secara kualitatif dilihat dari aktivitas keperawatan dan penggunaan waktu kerja perawat dengan jenis penyakit yang sama dan kategori perawatannya. 


\section{DAFTAR PUSTAKA}

1. Hidayat, A. A., \& Uliyah, M. Pengantar Kebutuhan Dasar Manusia. Jakarta: Salemba Medika, 2012.

2. Murwani, A. Keterampilan Dasar Praktik Klinik Keperawatan. Yogyakarta: Fitramaya, 2008.

3. Isro'in, L., \& Andarmoyo, S. Personal Hygiene Konsep, Proses dan Aplikasi dalam Praktik Keperawatan. Yogyakarta: Graha Ilmu, 2012.

4. Parinduri, J.S. Tingkat Kepuasan Pasien Imobilisasi terhadap Pelaksanaan Personal Higiene oleh Perawat di Rumah Sakit H. Adam Malik Medan. Medan: Universitas Sumatera Utara, 2009.

5. El-Soussi, A., \& Asfour, H. Examining Bed-Bath Practices Of Critically Ill Patients. Journal of Nursing Education and Practice, 6(12), 1-11, 2016.

6. Kharismawati, A. Hubungan Antara Beban Kerja Perawat Dengan Pelayanan Personal Hygiene Kepada Pasien Di Ruang Rawat Inap RSUD Banyumas. Universitas Muhammadiyah Purwokerto, 2013.

7. Romadhoni, R. D., \& Pudjirahardjo, W. J.Beban Kerja Obyektif Tenaga Perawat Di Pelayanan Rawat Inap Rumah Sakit. Jurnal Administrasi Kesehatan Indonesia, 4(1), 5766, 2016.

8. Saputra, R. T. Hubungan Beban Kerja Perawat Dengan Mutu Pelayanan Keperawatan Di Rawat Inap Rumah Sakit Umum Daerah Sultan Syarif Mohamad
Alkadrie Kota Pontianak. Pontianak: Universitas Tanjungpura, 2016.

9. Handayani, S., Fannya, P., \& Nazofah, P. Faktor Yang Berhubungan Dengan Kinerja Tenaga Kesehatan Di Rawat Inap RSUD Batusangkar. Padang: STIKES Saintika Padang, 2018.

10. Wahyudi, Sutria, E., Ashar, M., \& Syisnawati. Faktor - Faktor Yang Berhubungan Dengan Perilaku Caring Perawat Di Ruang Perawatan Interna. Journal Of Islamic Nursing, 2(2), 82-92, 2017.

11. Soeprodjo, R., Mandagi, C., \& Engkeng, S. Hubungan Antara Jenis Kelamin Dan Motivasi Kerja Dengan Kinerja Perawat Di Rumah Sakit Jiwa Prof. DR.V.L.Ratumbuysang Provinsi Sulawesi Utara. Manado: Universitas Sam Ratulangi, 2017.

12. Susanti, E. N. Hubungan Karakteristik Perawat Dengan Motivasi Perawat Dalam Pemenuhan Kebutuhan Kebersihan Diri Pasien Di Ruang Rawat Inap RSU dr. H. Koesnadi Bondowoso. Jember: Universitas Jember, 2013.

13. Malik, D. I. Hubungan Tingkat Pendidikan Perawat Dengan Mutu Pelayanan Keperawatan Pada Pasien Di Rumah Sakit Daerah Kalisat Jember. Jember: Universitas Muhammadiyah Jember, 2013

14. Elysabeth, D., Libranty, G., \& Natalia, S. Hubungan Tingkat Pendidikan Perawat Dengan Kompetensi Aplikasi Evidence- 
Based Practice. Jurnal Skolastik Keperawatan, 1(1), 14-2019.

15. Faizin, A. Hubungan Tingkat Pendidikan Dan Lama Kerja Perawat Dengan Kinerja Perawat Di RSU Pandan Arang Kabupaten Boyolali. Boyolali: Universitas Muhammadiyah Surakarta, 2017.

16. Abas, S. Y. Hubungan Status Kepegawaian Dengan Motivasi Kerja Perawat Dalam Pelaksanaan Asuhan Keperawatan Di Ruang Rawat Inap RSUD Toto Kabila Kabupaten Bone Bolango. Gorontalo: Universitas Negeri Gorontalo, 2015.

17. Agritubella, S. Kenyamanan dan Kepuasan Pasien dalam Proses Interaksi Pelayanan Keperawatan di RSUD Petala Bumi. Jurnal Edurance, 3(1), 14-26, 2018.

18. Afrilianti, A. N. Kepuasan Pasien Terhadap Mutu Pelayanan Rawat Inap Berdasarkan Metode Servqual Di RSUD Cilegon . Jakarta: Universitas Islam Negeri Syarif Hidayatullah, 2014.

19. Akbulut, G., Kant, E., Osmen, S., \& Akpinar, R. Determining Patients Satisfaction with the Nursing Services Provided in an Oncology Clinic of Eastern Turkey. International Journal of Caring Sciences, 10(3), 12761285, 2017.

20. Setiawan, I., \& Kariasa, I. Tingkat Kepuasan terhadap Pelayanan Perawat di Unit Gawat Darurat Rumah Sakit Haji Jakarta. Jurnal FK UI, 1-9, 2013.
21. Retnaningsih, D., \& Fatmawati, D. Beban Kerja Perawat Terhadap Implementasi Patient Safety Di Ruang Rawat Inap . Semarang: Jurnal Keperawatan Soedirman, 2016.

22. Bogaert, P., \& Clarke, S. The Organizational Context of Nursing Practice: Concepts, Evidence and Interventions For Improvement.

Cham Switzerland: $\quad$ Springer International Publishing, 2018.

23. Nikijuluw, F. Hubungan Antara Tindakan Personal Hygiene Perawat Dengan Kepuasan Pasien Imobilisasi Dengan Stroke Di Ruang Neurologi Di RSUD Dr.M. Haulussy Ambon. Ambon: Universitas Kristen Satya Wacana Salatiga, 2016.

24. Awiktamarotun. Hubungan Pemenuhan Personal Hygiene Dengan Tingkat Kepuasan Pasien Di RS PKU Muhammadiyah Yogyakarta. Yogyakarta: Sekolah Tinggi Ilmu Kesehatan Aisyiyah, 2014.

25. Isro'in, L., \& Andarmoyo, S. Personal Hygiene Konsep, Proses dan Aplikasi dalam Praktik Keperawatan. Yogyakarta: Graha Ilmu, 2012.

26. Runtu, V., Pondaag, L., \& Hamel, R. Hubungan Beban Kerja Fisik Dengan Stres Kerja Perawat Di Ruang Instalansi Rawat Inap Rumah Sakit Umum GMIM Pancaran Kasih Manado. e-Journal Keperawatan, 6(1), 17, 2018. 